\title{
ANALYSIS OF STUDENTS RESPONSE TOWARD THE IMPLEMENTATION OF ROUND TABLE TECHNIQUE IN WRITING FOR GENERAL COMMUNICATION COURSE
}

\author{
Aseptiana Parmawati ${ }^{1}$, Iman Santoso ${ }^{2}$ \\ ${ }^{1}$ English Education Department, IKIP Siliwangi \\ aseptiana@ikipsiliwangi.ac.id \\ ${ }^{2}$ English Education Department, IKIP Siliwangi \\ santoso@ikipsiliwangi.ac.id
}

\begin{abstract}
Writing is also a productive talent which is meant for communication to deliver messages in the shapesvof letters and symbols. In the course of writing for general communication, students are expected to be able to write using several genre of text. Round Table is one of teaching technique which is implemented by cooperative learning approach. The specific purpose of this study is to prove the students responses toward Round Table techniques in improving writing skills in the Writing for General Communication course. This research used a descriptive qualitative. The research conducted in the second semester students at IKIP Siliwangi in the academic year of 2019/2020. Purposive sample is the technique that the researchers taken. The subject of this research consist of 48 students. Questionnaire grid used as instrument in this research. After analyzing the data descriptively, the results show that all of the students were actively involved during the teaching and learning activity. They have a high motivation to learn. The students understand the material easier. The learning process is interesting and not boring. They are motivated to get good achievement because they feel more valued in expressing opinions when learning.
\end{abstract}

Keyword: Response, Writing, Round Table Technique

Abstrak: Menulis merupakan keterampilan produktif yang dimaksudkan untuk berkomunikasi guna menyampaikan pesan dalam bentuk huruf dan simbol. Dalam mata kuliah Writing for General Communication, siswa diharapkan dapat menulis menggunakan beberapa jenis teks. Round Table adalah salah satu teknik pengajaran yang dapat diimplementasikan dengan pendekatan pembelajaran yang bersifat kooperatif. Tujuan khusus dari penelitian ini adalah untuk dapat mengetahui bagaiman tanggapan mahasiswa terhadap penggunaan teknik Round Table dalam meningkatkan keterampilan menulis dalam mata kuliah Writing for General Communication. Penelitian ini merupakan penelitian deskriptif kualitatif. Penelitian ini dilaksanakan pada mahasiswa semester kedua di IKIP Siliwangi pada tahun akademik 2019/2020. Purposive sample adalah teknik pengambilan sampek yang digunakan oleh peneliti. Subjek penelitian ini terdiri dari 48 siswa. Kuisioner digunakan sebagai instrumen dalam penelitian ini. Setelah menganalisis data secara deskriptif, hasilnya menunjukkan bahwa semua siswa terlibat aktif selama kegiatan belajar mengajar. Mereka memiliki motivasi belajar yang tinggi. Siswa lebih mudah memahami materi. Proses pembelajarannya menarik dan tidak membosankan. Mereka termotivasi untuk mendapatkan prestasi yang baik karena mereka merasa lebih dihargai dalam mengekspresikan pendapat saat belajar

Kata kunci: Respon, Menulis, Teknik Round Table 


\section{INTRODUCTION}

Four core components that must be mastered by students in learning English. They are listening, speaking, reading and writing. The writing component must be mastered by students. Writing is also a productive skill which is meant for communication to deliver messages in the shapes of letters and symbols. Blanchard and Root (1998: 1) as cited in Mundriyah \& Parmawati (2016) state that learning to write in a new language is not always easy. Writing concerns on some aspects such as: content, organization, vocabulary, language, and mechanics. Peha (2010) as cited in (Sari, 2015) pointed out that a good writing should have ideas that are interesting and important, organization that is logical and effective, voice that is individual and appropriate, word choice that is specific and effective, sentence fluency that is smooth and expressive, and conventions that are correct and communicative.

Brown (2000:335) as cited in (Muflikhati, 2013) state that writing is a written product which is completed after the processof thinking, planning, drafting, and revising and also demands efforts and specialized skills of generating ideas, organizing them coherently, making use of the discourse markers and the rhetorical conventions, putting all of them into one, revising the content for a clearer meaning, and editing for accurate grammar into a final product. Moreover, Harmer (2004) as cited in Larasati (2015) states that writing is the only skill which enables learner to produce a real product, in which the product is touchable, readable, as well as keep able for a long period of time. In the course of writing for general communication, students are expected to be able to write using several genre of text.

Based on the observation while teaching the writing for general communication course, we found that most of the second semester students of the English Department of IKIP Siliwangi, still had difficulties in writing several text genres in English. This is due to several factors, including: 1) Difficulty in determining the theme or topic of writing, according to the genre of text they will write, 2) They do not know how to make good, coherent, and unifised paragraphs in their writing, so less focus; 3) Motivation in learning to write is lacking because learning techniques are still monotonous.

Many students assume that they are competing with each other. This is a special note from us. Basically through group work they can find alternative ways of learning by expressing and exploring a variety of ideas and experiences in a collaborative atmosphere. This is not about competing with fellow students and winning, but about using the various resources available in groups to deepen understanding, to sharpen assessments and expand knowledge. The various kinds of collaborative learning techniques, one of which can be applied is the Round Table technique.

Round Table is one of teaching technique which is implemented by cooperative learning approach. According to Johnson and Stanne (2000) as cited in Khaghaninezhadb\& Kaashef (2014) "cooperative language learning" is a cover term that covers numerous methods for organizing and conducting pedagogical activities in the way that any language teacher can find a way to employ its techniques in his or her instructional philosophies and practices. Sinaga (2017) promoted that roundtable is one of the teaching techniques which is used by the cooperative learning approach.

Rusinovci (2015) declared that the role of the process approach in the roundtable technique is as the systematic direction for students to write cooperatively in a group. Moreover, Sinaga (2017) as cited in Flora, Cahyadi, \& Sukirlan (2020) states that 
Roundtable teaching technique is a technique of brain-storming, reviewing or practicing skill in writing which is used to stimulate creativity and deeper thinking as the value of multiple view points and ideas as the result working in team. Round Table technique also encourages students to be active in learning process. Barkley, Cross and Major (2005: 243) as cited in Putri, Susilohadi, \& Sulistyawati (2017) state that the structure requires all students to post, and limits some group members from posting too frequently. It means that in Round Table every students need to contribute their ideas for the group's task. Through this learning technique, it is expected to be able to help students improve their writing skills in a good team /team.

The specific purpose of this study is to prove the students responses toward Round Table techniques in improving writing skills in the Writing for General Communication course.

\section{METHOD}

\section{Research Design}

This research used a descriptive qualitative. Miles and Huberman (1994) as cited in Latifah \& Rahmawati (2019) stated that qualitative research design conducted prolonged and intense contact with field or little situation. Qualitative research method is a research method based on the philosophy of positivism, used to examine natural object conditions (as opposed to experiments) where the researcher is the key instrument, purposive and snowball sampling, data collection techniques, data analysis inductive/qualitative, and the results of qualitative research emphasize more meaning than generalization, (Sugiyono, 2017) . Furthermore, Arikunto (2006) as cited in Purba (2018) said descriptive qualitative design used to describe occurrence, situation and event of basic data was conducted simultaneously with data collection. Qualitative research design discuss about reality and happened. It means that qualitative research design aims to understand the world symbolized meaning in people behavior in society itself.

\section{Subject of the Research}

The research conducted in the second semester students at IKIP Siliwangi in the academic year of 2019/2020. The subject of this research consist of 48 students. The campus is located at jl.Terusan Jenderal Sudirman no.3, Baros Cimahi Tengah, West Java. Purposive sample is the technique that the researcher taken. According to Suen, Huang, \& Lee (2014) the purposive sampling technique, also called judgment sampling, is the deliberate choice of a participant due to the qualities the participant possesses. It is a nonrandom technique that does not need underlying theories or a set number of participants. Simply put, the researchers decides what needs to be known and sets out to find people who can and are willing to provide the information by virtue of knowledge or experience.

\section{Instrument}

Instrument research is the aspect of the accumulation of data that conducted in scientific and as the way or tool used in collecting data. Questionnaire grid adopted from Muhlisin (2018) was used as instrument in this research. The purpose of questionnaire was to investigate the students' responses toward The Implementation of Round Table Technique in Writing for General Communication Course.

\section{RESULT AND DISCUSSION}

Students response towards implementation of Round Table Technique in Writing for General Communication Course. that surveyed by questionnaies with "Yes" and "No" choices in their answers. The students" 
responses questionnaire grid can be seen in table 1 and the precentage of Students' response toward The Implementation of Round Table Technique in Writing for
General Communication Course can be seen in figure 1. The precentage of student's response based on indicator can be seen in table 2 .

Table 1

Students' responses questionnaire grid

\begin{tabular}{|c|c|c|c|c|c|}
\hline No & Indicator & Variable & Description & Item & Item no \\
\hline \multirow{4}{*}{1} & \multirow{4}{*}{ Attention } & $\begin{array}{l}\text { Enjoy } \\
\text { learning }\end{array}$ & $\begin{array}{l}\text { Have a high } \\
\text { motivation to the } \\
\text { learn }\end{array}$ & $\begin{array}{l}\text { Did the learning that has } \\
\text { been implemented made } \\
\text { you have a high } \\
\text { willingness to follow the } \\
\text { lesson? }\end{array}$ & 1 \\
\hline & & $\begin{array}{l}\text { There is no } \\
\text { wrong } \\
\text { concept }\end{array}$ & $\begin{array}{l}\text { Eliminating the } \\
\text { wrong concept }\end{array}$ & $\begin{array}{l}\text { Is the learning that has } \\
\text { been implemented can } \\
\text { eliminate the concept of } \\
\text { mistakes in yourself }\end{array}$ & 2 \\
\hline & & $\begin{array}{l}\text { Improve } \\
\text { retension }\end{array}$ & $\begin{array}{l}\text { Concepts can be } \\
\text { remembered } \\
\text { longer/meaningful }\end{array}$ & $\begin{array}{l}\text { As the learning that has } \\
\text { been implemented gives } \\
\text { meaning and makes it } \\
\text { easier to understand the } \\
\text { material? }\end{array}$ & 3 \\
\hline & & $\begin{array}{l}\text { Easy to } \\
\text { understand } \\
\text { material of } \\
\text { the course }\end{array}$ & $\begin{array}{l}\text { Understand the } \\
\text { material easier }\end{array}$ & $\begin{array}{l}\text { Does learning make you } \\
\text { easy to understand the } \\
\text { material being taught? }\end{array}$ & 4 \\
\hline \multirow[b]{2}{*}{2} & \multirow[b]{2}{*}{ Relevance } & Not boring & $\begin{array}{l}\text { Interesting and } \\
\text { not boring }\end{array}$ & $\begin{array}{l}\text { Is the learning } \\
\text { interesting, fun, and not } \\
\text { boring? }\end{array}$ & 5 \\
\hline & & $\begin{array}{l}\text { Reduce the } \\
\text { time needed } \\
\text { to master } \\
\text { the concept } \\
\text { of learning }\end{array}$ & $\begin{array}{l}\text { Time needed to } \\
\text { master the } \\
\text { concept of } \\
\text { learning shorter }\end{array}$ & $\begin{array}{l}\text { Do you feel the time } \\
\text { spent in understanding } \\
\text { the concept is getting } \\
\text { shorter? }\end{array}$ & 6 \\
\hline \multirow[b]{2}{*}{3} & \multirow[b]{2}{*}{ Confidence } & $\begin{array}{l}\text { Motivated to } \\
\text { learn }\end{array}$ & $\begin{array}{l}\text { Motivated to get } \\
\text { achievement }\end{array}$ & $\begin{array}{l}\text { Are you motivated to get } \\
\text { good achievement? }\end{array}$ & 7 \\
\hline & & $\begin{array}{l}\text { Improving } \\
\text { writing skill }\end{array}$ & $\begin{array}{l}\text { writing skill is } \\
\text { improved }\end{array}$ & $\begin{array}{l}\text { Does the learning can } \\
\text { improved your writing } \\
\text { skill? }\end{array}$ & 8 \\
\hline \multirow{2}{*}{4} & \multirow{2}{*}{ Satisfaction } & $\begin{array}{l}\text { Rewarded in } \\
\text { expressing } \\
\text { opinions }\end{array}$ & $\begin{array}{l}\text { More appreciated } \\
\text { in expressing } \\
\text { opinions }\end{array}$ & $\begin{array}{l}\text { Do you feel more valued } \\
\text { in expressing opinions } \\
\text { when learning? }\end{array}$ & 9 \\
\hline & & $\begin{array}{l}\text { Dare to } \\
\text { express } \\
\text { opinions }\end{array}$ & $\begin{array}{l}\text { Dare to deliver } \\
\text { opinions }\end{array}$ & $\begin{array}{l}\text { Do you feel braver in } \\
\text { delivering your opinion? }\end{array}$ & 10 \\
\hline
\end{tabular}


Figure 1

The precentage of students' response

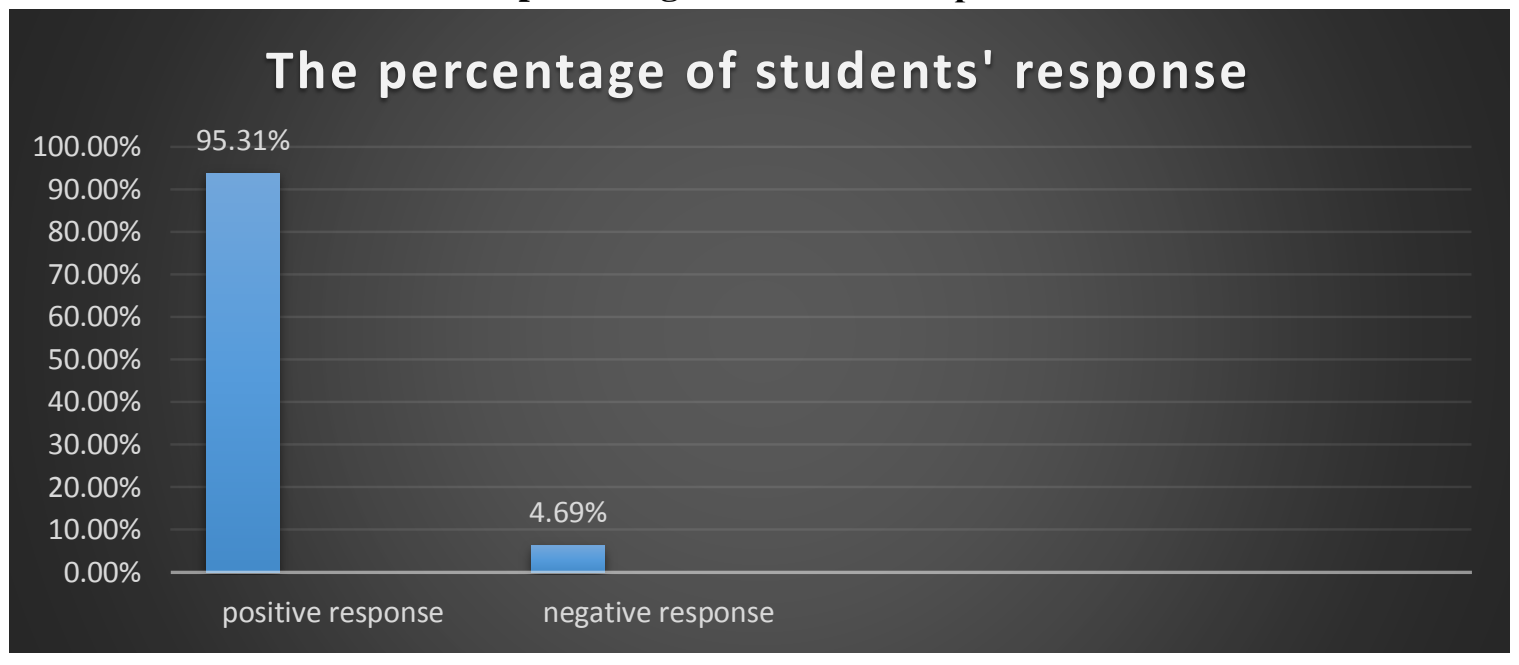

Table 2

The precentage of student's response based on indicator

\begin{tabular}{ccc}
\hline Indicator & Yes & No \\
\hline Attention & $95.83 \%$ & $4.17 \%$ \\
\hline Relevance & $97.91 \%$ & $2.09 \%$ \\
\hline Confidence & $93.75 \%$ & $6.25 \%$ \\
\hline Satisfaction & $93.75 \%$ & $6.25 \%$ \\
\hline
\end{tabular}

Based on table 2 that consist of four criterias (attention, relevance, confidence, and satisfaction), it can be conclude that majority of students give positive response towards the implementation of round table technique in writing for general communication course. Round Table technique which is seen as both cooperative and collaborative learning technique was able to change the teaching and learning activity into learnercentered. All of the students were actively involved during the teaching and learning activity. They have a high motivation to learn. The students understand the material easier. The learning process is interesting and not boring. They are motivated to get good achievement because they feel more valued in expressing opinions when learning.

\section{CONCLUSION}

Based on data analysis and discussion that has been explained then it can be concluded as follows: 1) Student response after implementation of round table technique gave positive respons. 2) Student's positive response is shown by their activeness in writing for general communication course. 3) The lecturer should use the cooperative learning in the writing activity, so that the students can improve their writing skills by sharing their ideas to others.

\section{REFERENCE}

Flora, F., Cahyadi, D. S., \& Sukirlan, M. (2020). A Modified Roundtable Technique Based On Process Approach To Promote The Students'writing Achievements In 
Foreign Language Setting. International Journal Of Education And Practice, 8(1), 149-157.

Khaghaninezhad, M. S., \& Kaashef, F. (2014). Applying cooperative language learning techniques in Iranian ELT context. International Journal of Language Learning and Applied Linguistics World (IJLLALW), 5(3), 313-323.

Larasati, A. (2015). Improving students' writing skills through project based learning technique at grade XI SMAN 2 Sleman in the academic year of 2014/2015. Yogyakarta state university, yogyakarta.

Latifah, N., \& Rahmawati, I. N. (2019). ). Teaching And Learning Narrative Text Writing Through Story Mapping. English Education: Jurnal Tadris Bahasa Inggris, 12(1), 78-96.

Muflikhati, A. (2013). Improving Students Writing Skills on Recount Texts Through the Use of Dialogue Journal Writing of the Tenth Grade Students of SMA IT Abu Bakar Yogyakarta in the Academic Year of 2012/2013. Yogyakarta: State University of Yogyakarta.

Muhlisin, A. (2018). Analysis Of Students'response Of The Implementation Of Rms (Reading, Mind Mapping, And Sharing) Learning Model In Philosophy Of Science. Unnes Science Education Journal, 7(1).

Mundriyah, M., \& Parmawati, A. (2016). Using Think-Pair-Share (Tps) To
Improve Students'writing Creativity (A Classroom Action Research In The Second Semester Students Of Stkip Siliwangi Bandung). Jurnal Ilmiah P2m Stkip Siliwangi, 3(2), 84-91.

Purba, D. (2018). Deixis In John Legend's Songs. Jurnal Littera: Fakultas Sastra Darma Agung, 1(2), 76-84.

Putri, N. E., Susilohadi, G., \& Sulistyawati, H. (2017). The Use of Round Table Technique to Improve Students' Writing Skill. English Education, 5(3).

Rusinovci, X. (2015). Teaching writing through process-genre based approach. US-China Education Review, 5(10), 699-705.

Sari, N. P. (2015). Improving Students' Writing Skills In Narrative Text By Using Semantic Mapping. Jurnal Pendidikan Edutama, 2(1), 1-13.

Sinaga, M. (2017). The Effect of Roundtable and Clustering Teaching Techniques and Students' Personal Traits on Students' Achievement in Descriptive Writing. Advances in Language and Literary Studies, 8(6), 69-75.

Suen, L. J. W., Huang, H. M., \& Lee, H. H. (2014). A comparison of convenience sampling and purposive sampling. $\mathrm{Hu}$ Li Za Zhi, 61(3), 105.

Sugiyono, P. D. (2017). Metode Penelitian Bisnis: Pendekatan Kuantitatif, Kualitatif, Kombinasi, dan $R \& D$. 